\title{
A STUDY OF NON-PERFORMING ASSETS WITH SELECTED SCHEDULED COMMERCIAL BANKS
}

\section{Dr. Bhavsinh M Dodia}

\section{ABSTRACT}

The banking sector reforms measures since 1991, had epoch-making/ likely to have a significant effect on a particular period of time changes for banking activities with international standard. Earlier, profits were seldom a matter of serious concern to banks. Deposit mobilization was the main goal. These by gone days profit became a driving force through cutting of operational cost. The earning capacity and profitability in many banks is affected by NPA, which affects the liquidity, profitability and equity. In recent time the reduction of NPAs in banks is biggest challenges in the Indian economy. An attempt of present study that knows RBI guidelines regarding NPA recognition, classification and provisioning and an effort to made evaluate the operational performance of selected 10 Public Sector Banks and 10 Private Sector Banks with using various statistical tool\& techniques like Mean, Standard deviation and ANOVA test used to analyzed data.

Key Words: - NPA, Substandard Assets, Doubtful Assets, Loss Assets, Trend, Ratio, ANOVA

\section{INTRODUCTION:}

The banking sector is the life line of modern economy. It is one of the important financial pillars of financial system, which plays vital role in the success of the economy. The importance of the banks in the process of economic development has been stressed from time to time by the economic thinkers and progressive bankers in the country. Banking is different from money lending. Banking has two important functions to perform, one of accepting deposits and other of lending money and investment of fund and the rates of interest allowed on deposits and charged on 
advances generally remain known and reasonable. A Banker shall be very careful in lending money because is not lending money of his own capital; a major portion of money lent comes from the deposits received from the public.

Non-Performing Assets (NPA) is an important one, because credit is essential for economic growth and NPAs affect the smooth flow of credit. The major concern for any bank is the efficient management of its loan accounts. If proper credit evaluation is done at the time of advancing loans then the ratio of NPAs to loan accounts can be reduced. In the context of banks, an asset is defined as a NPA when interest and/or principal amount becomes past due for 90 days, with effect from March 31, 2005 as against 180 - days earlier. NPAs are shown under two heads: Gross and Net NPAs. Gross NPA is the amount which is outstanding in the books, regardless of any interest recorded and debited. Net NPA is Gross NPA less interest debited to borrowed account and not recovered or recognized as income.

\section{Assets Classification: -}

Generally, three ways of classification of assets, which are given as under:

- Asset classification under Health Code System.

- Asset classification for final accounts as per Third Schedule of Banking Regulation Act, 1949.

- Asset classification under prudential norms.

Under the prudential norms of asset classification, banks are required to classify NPA further into the following four categories based on the period for which the asset has remained non-performing and the reliability of the dues.

\section{Standard Assets:}

Standard/Performing asset is one which does not disclose any problem and does not carry more than normal business risk. The arrears of interest and the principal amount of loan do not exceed 90 days at the end of financial year with effect from March 31,2005 . It's required a minimum of $0.40 \%$ provisions on global portfolio but not on domestic portfolio.

\section{Sub - standard Assets:}

A Sub-standard asset would be one which has remained NPA for a period less than or equal to 12 months with effect from March 31, 2005 and it's required a general provision of $15 \%$ as par revised rate. 


\section{Doubtful Assets:}

A doubtful asset is one which has remained in the sub-standard category for 12 months with effect from March 31, 2005. On this asset the bank are required to provide $100 \%$ for the unsecured portion and in regard to the secured portion provisioning may be made $25 \%$ if doubtful up to 1 year, $40 \%$ if doubtful for 1 year and up to 3 years and $100 \%$ if doubtful more than 3 years as par revised rate.

\section{Loss Assets:}

A loss asset is one where loss has been identified by the bank thought the amount has not been written of wholly. If the assets permitted to remain in the books for any reason $100 \%$ provision of the outstanding balance should be made.

From the above discussion observed that NPA will be either classified as substandard or loss asset at the first instance. After it had become sub-standard asset then only it can become doubtful. The doubtful asset can also become loss asset. This can be easily shown by the following diagram.

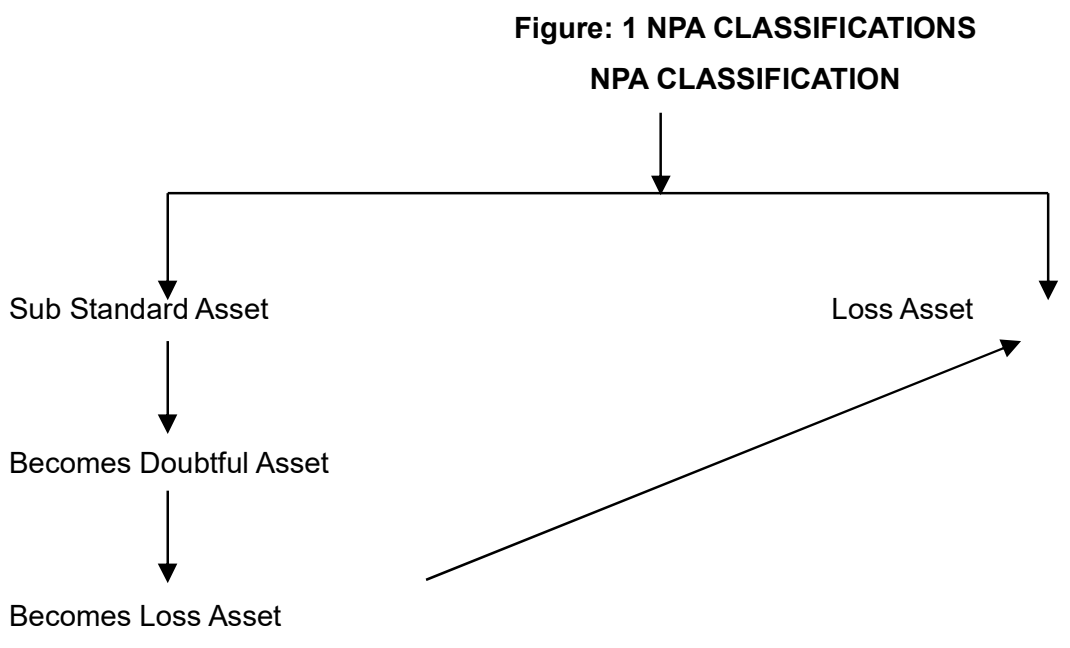

\section{LITERATURE REVIEW:}

Review of literature make the researcher familiar with what is already known and unproved and give basis for formulation hypothesis. R.K. Raul \& Jayand Uddin Ahmed, an attempt has been made to study the nature and substantial affect of the NPAs on the banking sector along with the measures adopted to arrest its growing menace. Both statistical and financial tools were applied over the financial data based on RBI bulletin to assess the significant impact on the banking activities. Dr. Jafor Ali Ahan, an attempt to high light the present level of NPAs of NBFC and different reasons thereon along with different remedial measure to control NPAs. The covers only those 
NBFCs which are registered with the RBI as deposit taking institutions. The analysis of the study is NPAs of NBFCs activity wise, classification of NBFC functions-wise. Renu Jatana, rightly point out the fact that the NPAs has affected the profitability, liquidity and competitive functioning of banks and finally the psychology of bankers with the references of Oriental Bank of Commerce, ICICI Bank and SBI and gave a comparative picture of interest loss for selected banks. Prof. N.B. Dey, introduce and explain NPAAct regarding the bank. The researcher has analysed some of important provisions of the NPA Act, its impact on banking and the latent loopholes in it. Dr. Sarita Aggarwal, studied the prudential norms for assets classification and management of NPAs as per the global norms and also introduces various recovery channels and measures to containing NPAs. R.M. Shrivastava, studied conceptually management of NPAs in commercial bank, finding revealed the concept of NPA norms, position of Indian Banks VIS-VIS other countries, affecting factor and suggestion for containing NPAs sector-wise. Sakariya Sima vasantbhai, evaluate the operational performance, NPA trend of the selected two public sector banks and also try to analyze how efficiency public sector banks have been managing NPA with various financial tools and techniques.

\section{OBJECTIVE OF THE STUDY:}

1. To study the nature of NPA in selected banks.

2. To study the RBI Guidelines for Assets classification.

3. To examine which category of the NPAs, i.e. Sub-standard Assets, Doubtful Assets and Loss Assets which is prominent in total NPAs.

\section{HYPOTHESIS:}

$\mathrm{H}_{0}$ :

1. There would be no significance difference in average category-wise NPAs as percentage in PSBs group.

2. There would be no significance difference in average category-wise NPAs as percentage in PvSBs group.

$H_{1}$ :

1. There would be significance difference exists in average category-wise NPAs as percentage in PSBs group. 
2. There would be significance difference exists in average category-wise NPAs as percentage in PvSBs group

\section{RESEARCH METHODOLOGY:}

In this research researcher has been selected 10 public sector banks i.s. Andhara Bank, Bank of Baroda, Bank of India, Canara Bank, Corporation Bank, Dena Bank, Indian Bank, Indian Overseas Bank, Punjab \& Sind Bank, United Bank of India and 10 private sector banks i.e. Axis Bank, City Union Bank, Federal Bank, HDFC Bank, Inducing Bank, Karnataka Bank, Karur Vysya Bank, Lakshmi Vilas Bank, South Indian Bank, Yes Bank randomly for comparative study. The period covers for the study is 10 year from $2007-08$ to $2016-17$. The study is based on secondary data and the the data has been collected from the published annual report of the banks, banks website, journals and publish record. In research various statistical tools ratio, mean, standard deviation and ANOVA F-test have been used to analyze data. The study is exploratory and analytical in nature so the significance of the study is very high. Further, some observations may be useful to the bankers. Here scope is the study of all Nationalized Banks, PSBs, PvSBs and Foreign Banks region-wise and make comparison by using other more ratios.

Non-Performing Assets- Category wise:-

TABLE: 1

Average Non-Performing Assets - Category wise in Selected PSBs Under Study

(Rs. in Crore)

\begin{tabular}{|c|c|c|c|c|c|c|c|}
\hline \multirow[t]{2}{*}{ Year } & \multicolumn{2}{|c|}{$\begin{array}{c}\text { Sub-standard } \\
\text { Assets }\end{array}$} & \multicolumn{2}{|c|}{ Doubtful Assets } & \multicolumn{2}{|c|}{ Loss Assets } & \multirow[t]{2}{*}{$\begin{array}{c}\text { Total NPA }= \\
A+B+C\end{array}$} \\
\hline & Amount & $\%$ & Amount & $\%$ & Amount & $\%$ & \\
\hline $2007-08$ & 620.80 & 51.12 & 431.43 & 35.53 & 162.13 & 13.35 & 1214.36 \\
\hline $2008-09$ & 545.65 & 47.03 & 512.04 & 44.13 & 102.55 & 8.84 & 1160.24 \\
\hline $2009-10$ & 908.36 & 52.37 & 636.30 & 36.69 & 189.77 & 10.94 & 1734.43 \\
\hline
\end{tabular}


Towards Excellence: An Indexed, Refereed \& Peer Reviewed Journal of Higher Education / Dr. Bhavsinh Dodia/ Page 127-136

\begin{tabular}{|c|c|c|c|c|c|c|c|}
$2010-11$ & 869.63 & 45.04 & 895.82 & 46.39 & 165.49 & 8.57 & 1930.94 \\
\hline $2011-12$ & 1571.78 & 57.89 & 1054.51 & 38.84 & 88.66 & 3.27 & 2714.95 \\
\hline $2012-13$ & 2755.36 & 61.35 & 1599.83 & 35.62 & 135.84 & 3.02 & 4491.03 \\
\hline $2013-14$ & 3299.39 & 48.67 & 3227.62 & 47.61 & 252.42 & 3.72 & 6779.43 \\
\hline $2014-15$ & 3864.61 & 38.60 & 5817.44 & 58.10 & 329.91 & 3.30 & 10011.96 \\
\hline $2015-16$ & 7507.33 & 35.79 & 12634.48 & 60.23 & 835.70 & 3.98 & 20977.51 \\
\hline $2016-17$ & 5902.79 & 24.70 & 16990.79 & 71.11 & 1001.11 & 4.19 & 23894.69 \\
\hline Total & 27845.70 & 462.56 & 43800.26 & 474.25 & 3263.58 & 63.18 & 74909.54 \\
\hline Average & $\mathbf{2 7 8 4 . 5 7}$ & $\mathbf{4 6 . 2 6}$ & $\mathbf{4 3 8 0 . 0 3}$ & $\mathbf{4 7 . 4 3}$ & $\mathbf{3 2 6 . 3 6}$ & $\mathbf{6 . 3 2}$ & $\mathbf{7 4 9 0 . 9 5}$ \\
\hline
\end{tabular}

(Source: Computed From Annual Report of the Selected PSBs)

Figure: 2

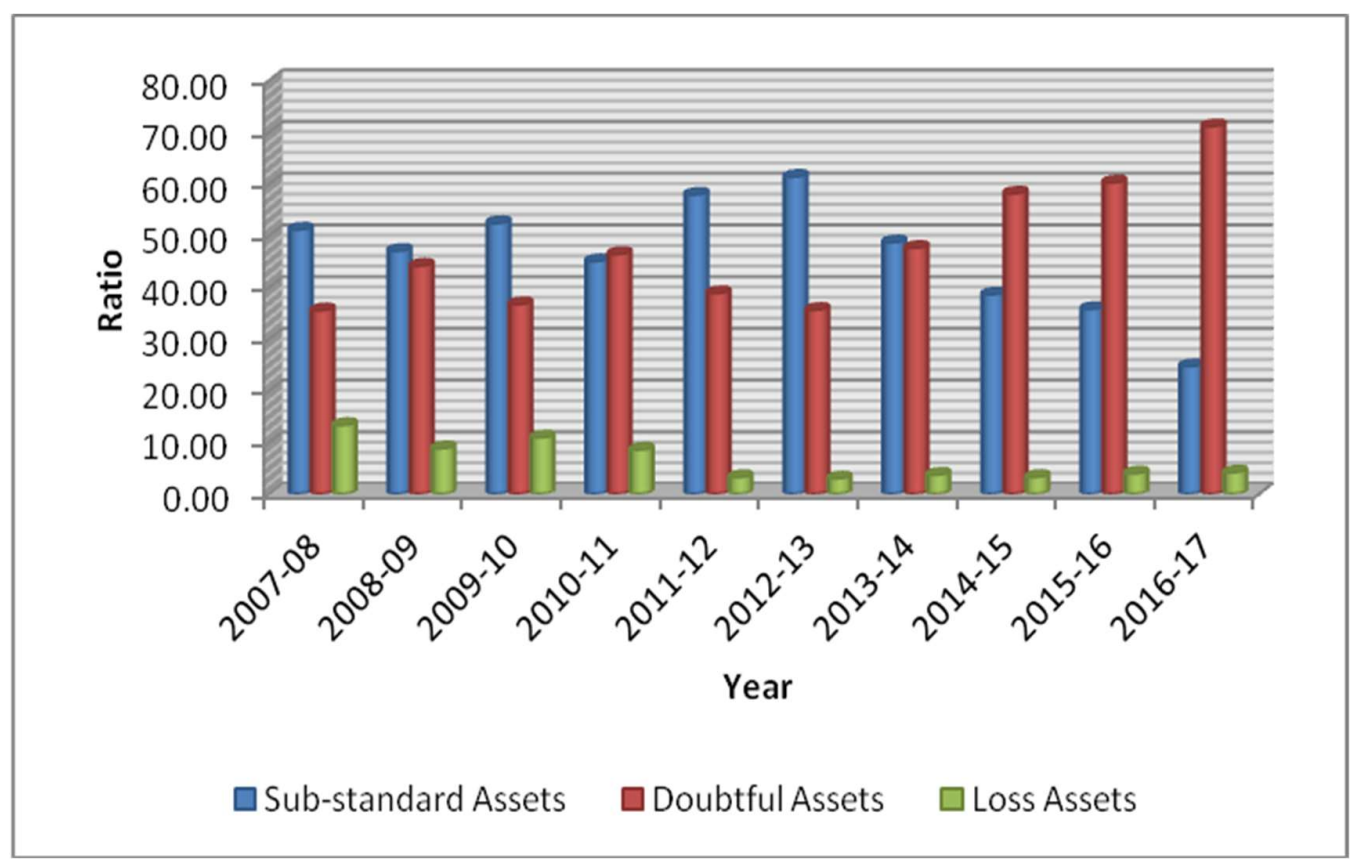

\section{Analysis:}


Table-1 and Figure:2 shows a category-wise NPAs of PSBs group that registered a fluctuating trend in Sub-standard, doubtful and loss assets. Sub-standard assets were prominent in generating NPAs from 2007-08 to 2013-14 and then second position from 2014-15 to 2016-17. The average sub-standard was $46.26 \%$ and which was at second position. Doubtful assets was second position in generating NPAs for year 2007-08 to 2013-14 and then at the first position from 2014-15 to 2016-17 and the average was $47.43 \%$. Loss assets were remaining at third position and it called good NPAs management.

TABLE: 2

\section{Average Non-Performing Assets - Category wise in Selected PvSBs Under Study}

(Rs. in Crore)

\begin{tabular}{|c|c|c|c|c|c|c|c|}
\hline \multirow[t]{2}{*}{ Year } & \multicolumn{2}{|c|}{$\begin{array}{c}\text { Sub-standard } \\
\text { Assets }\end{array}$} & \multicolumn{2}{|c|}{ Doubtful Assets } & \multicolumn{2}{|c|}{ Loss Assets } & \multirow[t]{2}{*}{$\begin{array}{c}\text { Total NPA= } \\
\qquad A+B+C\end{array}$} \\
\hline & Amount & $\%$ & Amount & $\%$ & Amount & $\%$ & \\
\hline $2007-08$ & 336.36 & 56.65 & 141.56 & 23.84 & 115.79 & 19.50 & 593.71 \\
\hline $2008-09$ & 338.53 & 63.94 & 117.25 & 22.14 & 73.69 & 13.92 & 529.47 \\
\hline $2009-10$ & 281.50 & 49.46 & 152.41 & 26.78 & 135.21 & 23.76 & 569.12 \\
\hline $2010-11$ & 231.18 & 37.15 & 222.83 & 35.80 & 168.35 & 27.05 & 622.36 \\
\hline $2011-12$ & 307.07 & 42.38 & 220.93 & 30.49 & 196.54 & 27.13 & 724.54 \\
\hline $2012-13$ & 345.04 & 38.92 & 333.75 & 37.65 & 207.72 & 23.43 & 886.51 \\
\hline 2013-14 & 477.22 & 45.37 & 373.92 & 35.55 & 200.62 & 19.07 & 1051.76 \\
\hline 2014-15 & 520.44 & 40.97 & 500.73 & 39.42 & 249.04 & 19.61 & 1270.21 \\
\hline $2015-16$ & 771.64 & 42.55 & 791.59 & 43.65 & 250.08 & 13.79 & 1813.31 \\
\hline $2016-17$ & 1373.07 & 36.16 & 1755.62 & 46.23 & 668.74 & 17.61 & 3797.43 \\
\hline
\end{tabular}




\begin{tabular}{|c|c|c|c|c|c|c|c|} 
Total & 4982.05 & 453.56 & 4610.59 & 341.57 & 2265.78 & 204.87 & 11858.42 \\
\hline Average & $\mathbf{4 9 8 . 2 1}$ & $\mathbf{4 5 . 3 6}$ & $\mathbf{4 6 1 . 0 6}$ & $\mathbf{3 4 . 1 6}$ & $\mathbf{2 2 6 . 5 8}$ & $\mathbf{2 0 . 4 9}$ & $\mathbf{1 1 8 5 . 8 4}$ \\
\hline
\end{tabular}

(Source: Computed From Annual Report of the Selected PvSBs.)

Figure: 3

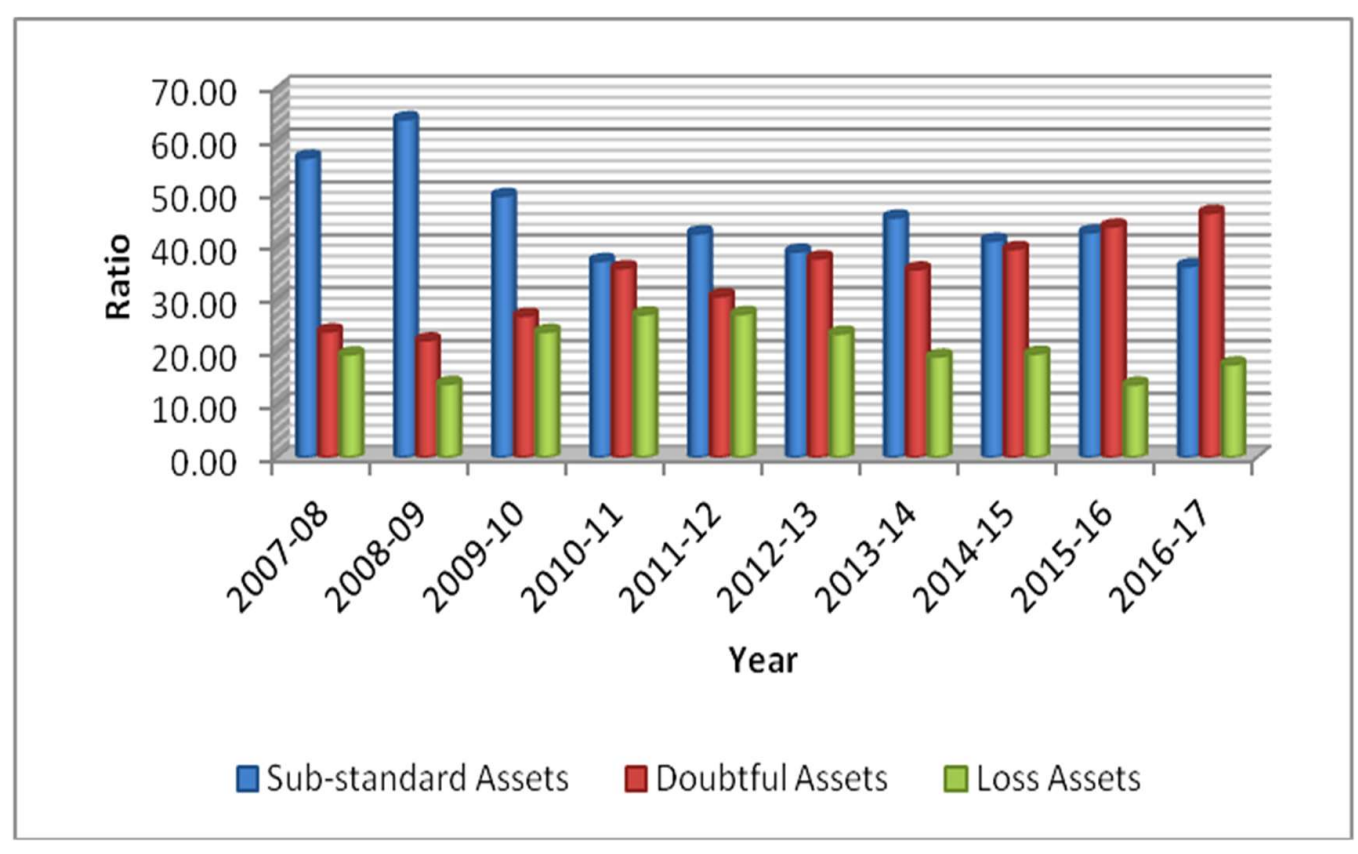

\section{Analysis:}

Table 2 and Figure: 3 shows category-wise NPAs of PvSBs group and that also registered a fluctuating trend. Sub-standard assets were prominent in generating NPAs except the year 2016-17 followed by doubtful and loss assets. Average loss assets were very high level at $20.49 \%$ and it bad indicator for banks to reduce NPAs and banks have been to suffer.

TABLE: 3

Analysis of One-Way ANOVA

\begin{tabular}{|c|c|c|c|c|c|c|c|}
\hline Group & $\begin{array}{c}\text { Source } \\
\text { of } \\
\text { Variation }\end{array}$ & SS & D.F. & MS & F-Value & $\begin{array}{c}\text { Table } \\
\text { Value }\end{array}$ & $\mathrm{H}_{0} / \mathrm{H}_{1}$ \\
\hline PSBs & $\begin{array}{c}\text { Between } \\
\text { Sample }\end{array}$ & 10953.946 & 2 & 5476.973 & 58.82328 & 3.3541308 & $\mathrm{H}_{1}$ \\
\hline
\end{tabular}




\begin{tabular}{|c|c|c|c|c|c|c|c|}
\hline & $\begin{array}{l}\text { Within } \\
\text { Sample }\end{array}$ & 2513.9413 & 27 & 93.108936 & & & \\
\hline & Total & 13467.887 & 29 & & & & \\
\hline \multirow[t]{3}{*}{ PvSBs } & $\begin{array}{l}\text { Between } \\
\text { Sample }\end{array}$ & 3102.56 & 2 & 1551.2811 & \multirow{3}{*}{27.470631} & \multirow{3}{*}{3.3541308} & \multirow{3}{*}{$\mathrm{H}_{1}$} \\
\hline & $\begin{array}{l}\text { Within } \\
\text { Sample }\end{array}$ & 1524.7 & 27 & 56.470531 & & & \\
\hline & Total & 4627.27 & 29 & & & & \\
\hline
\end{tabular}

\section{CONCLUSION:}

Sub-standard assets ratio indicates the scope for improvement in NPAs and the higher ratio indicate the batter is position of recovering the advances. Doubtful assets is the stage where banks can recover more of the advances through compromise and the higher ratio indicates more scope for compromising and reducing in NPAs. Loss assets ratio shows portion of loan loss that the banks are likely to suffer as compared to gross NPAs and higher ratio indicates high loss and lower ratio indicate the lost would be lower as compared to gross NPAs, this ratio must be a minimum. 


\title{
References
}

1. R.K. Raul \& Jaynal Uddin Ahmed, "Public Sector Banks in India, Impact of Financial Sector Reforms", Kalpaz Publication, Delhi - 2005.

2. Parul Bhatia, "Loans by Banks Post - Recession the NPA Effect", Professional Banker, May - 2009, P.N. 55.

3. Dr. Jaynal Ud-Din Ahmed, "Management of NPA of Commercial Bank in India", The Management Account, June - 2009 P.N. 470.

4. S.N. Bidani, "Managing Non-Performing Assets in Banks" Vision Book Pvt. Ltd. P.N. 13.

5. Dr. Jafor Aliakhan, "NPA Management of Non-Banking Financial Companies: An Introduction", The Management Account, February 2009 P.N. 132.

6. Renu Jatana, "Impact of NPAs on Profitability of Banks", Indian Journal of Accounting, June - 2009.

7. Prof. N.B. Dey, "Banking and the NPAAct", Professional Banker, April - 2009.

8. Dr. Sarita Aggarwal "Non-Performing Assets - A Benchmark for Banking Sector", Professional Banker, August - 2009.

9. R.M. Shrivastava "Management of Indian Financial Institutions", Divya Nigam Publication.

10. Sakariya Sima Vasantbhai, "A Comparative Analysis of NPA Management between SBI and CBI", Indian Journal of Research. Vol.-2, Issue-4, April-2013.

11. RBI Trend and Progress Report on Banking in India from 2007-08 to 2016-17.

12. Annual Report of selected PSBs and PvSBs from 2007-08 to 2016-17.

13. www.rbi.org.in

\author{
Dr. Bhavsinh M Dodia \\ Associate Professor \\ Department of commerce and Management \\ BKNM University, Junagadh (Gujarat) \\ bhavsinhdodia@yahoo.com
}

